\title{
The institutionalisation of mining company sustainability disclosures
}

\author{
Charl de Villiers \\ The University of Waikato and University of Pretoria \\ Mary Low \\ The University of Waikato \\ Grant Samkin \\ The University of Waikato
}

\begin{abstract}
This paper reports the analyses of the social and environmental disclosures of listed South African mining companies and compares the disclosures of larger companies with those of smaller companies using several different categories of comparison. The prior literature suggests that larger companies almost invariably disclose more social and environmental information due to their greater visibility. The expected differences are found in social disclosures, but not in environmental disclosures. An institutional theory framework is used to explain these unexpected environmental disclosure findings. Specifically, the field of corporate environmental disclosures among mining companies may have reached a level of maturity and professionalization causing disclosures to become similar through a process of isomorphism. These similarities have now reached the stage where small companies disclose the same amount of environmental information, in the same general format, as large companies. While all three types of isomorphism (mimetic, coercive, normative) are probably still at work, in theory normative isomorphism, usually driven by professionalization, becomes more prominent when a field reaches maturity.
\end{abstract}

Keywords: Sustainability disclosure; Sustainability reporting; CSR disclosure; Environmental disclosure; Social disclosure; Mining; Institutionalisation

\section{Introduction}

This paper uses an institutional theory framework to examine the maturity of the corporate sustainability disclosure field. The examination entails comparing the social and the 
environmental reporting of large and small listed South African mining companies. Although social and environmental disclosures have been studied from a number of perspectives, e.g., the influence of stakeholder groups (Deegan and Blomquist, 2006) and media attention (Brown and Deegan, 1998) on disclosure, as far as could be ascertained, the maturity of the sustainability field has yet to be the subject of examination.

A major aspect of a mining company's sustainability agenda is its reporting. This reporting provides a platform for stakeholder engagement. Sustainability disclosure has its roots in the corporate social and environmental reporting that commenced during the 1960s/70s. Since then, both the extent and number of companies disclosing sustainability information has increased (Gray et al., 1996; KPMG, 2011). Initially, reporting was prompted by pressures stemming from changing societal expectations. Society (read stakeholders) questioned whether companies had the right to ignore the social and environmental consequences of their activities.

Organisations that are perceived by society as being legitimate are able to more easily access vital resources (DiMaggio and Powell, 1983; Scott, 2008a; Heugens and Lander, 2009), including finance, custom, and labour. Organisations demonstrate this legitimacy through adopting rules and structures society deems necessary (Deephouse, 1996).

As societal norms evolve, so do pressures on companies, sometimes leading to the development of a new field, e.g., sustainability disclosure. Managers are typically uncertain how to deal with new pressures and do not know which rules and structures to respond with in order to maintain the appearance of legitimacy. One of the strategies managers adopt is to mimic successful competitors, which over time results in rules and structures converging (DiMaggio and Powell, 1983; Tuttle and Dillard, 2007). As a field, for example sustainability disclosures, develops, matures and becomes widely accepted, it increasingly becomes the subject of regulation and/or increased stakeholder pressure. This coerces more companies 
into adopting these legitimising rules and structures (Deephouse, 1996). As a field matures, consulting practices are set up to assist companies to implement these innovations (Mizruchi and Fein, 1999) while professional bodies are formed to regulate practice. As the new field and its associated rules and structures become accepted, they become incorporated into the formal education system. Corporate managers and consultants attend seminars and continuing education courses at universities, while the newly graduated join the professional bodies. At this stage in the development of a field, a consensus develops among professionals about the normatively appropriate forms of practice (DiMaggio and Powell, 1983). At this mature stage in the development of a field, the rules and structures adopted by organizations occupying the same position in the field have converged even further (Tuttle and Dillard, 2007). These generalised notions around the development of a new field apply to sustainability disclosure.

Voluntary disclosure of social and environmental information is an example of rules and structures implemented by companies when responding to societal pressures. Initially disclosures were innovative and varied. However, benchmarking led to some convergence, while disclosure rules were promulgated. Additionally stakeholder pressure, coupled with an increasing acceptance of disclosure frameworks (such as the Global Reporting Initiative (GRI)), encourages more companies to undertake sustainability disclosure. Consultants assist companies with the form, content, and assurance of their sustainability disclosures. As a discipline, sustainability disclosure is now widely incorporated in university curricula and the subject of extensive academic research. There is thus a growing consensus that sustainability disclosure the right thing to do.

Or is the view that sustainability disclosure should be undertaken only a minority view? Large companies are subject to greater scrutiny and pressure around the social and environmental impacts of their activities. This is consistent with both survey and empirical findings showing that large companies are more likely to disclose sustainability information 
(Gamble et al., 1996; Neu et al., 1996; Wong and Fryxell, 2004; Hasseldine et al, 2005; KPMG, 2011). However, if sustainability disclosure has reached the level of maturity associated with professionalization and the view that disclosure is the right thing to do, then it would be expected that all companies, including large and small companies, would undertake equal amounts of sustainability disclosure. Employee health and safety can be taken as an example of a field first taken seriously by larger companies, but that is now taken-for-granted by large and small companies. Similar developments can be seen in the field of sustainability disclosure assurance services (O’Dwyer et al., 2011).

This paper posits that if sustainability disclosure has not reached the level of maturity associated with professionalization, and a taken-for-granted view that such reporting should be undertaken, then large companies will disclose more information than small ones. However, because smaller companies are also managed and advised by professionals, if sustainability disclosure has reached the level of maturity associated with professionalization and taken-for-grantedness, equal amounts of information will be disclosed regardless of size.

Drawing on Tilt (2008), and De Villiers and Van Staden (2011) in terms of including disclosure media other than the annual report, this paper examines the maturity of the field of corporate sustainability disclosure. This is achieved by comparing the social and the environmental disclosures made by large and small companies in their annual reports and on their websites. To ensure that the companies are comparable in all other respects, e.g. the same industry and the same country, South African mining companies were used. To ensure data availability, the companies are all listed and to ensure that they are subject to the same societal and institutional pressures, they are only listed on the Johannesburg Stock Exchange, that is, they are not cross-listed on another stock exchange where different rules and pressures may apply. The content analysis is comprehensive in the sense that it includes both annual 
report and website disclosures. As stand-alone sustainability reports are generally disclosed on websites they are included as part of the website disclosure content analysis.

The paper compares social and environmental disclosures separately. While the study found that large companies disclosed more social information, environmental disclosures were found to be similar. From this analysis, it was concluded the field of environmental disclosures in the mining industry has reached a level of maturity where they are a taken-forgranted requirement by large and small company managers. Therefore, the level of conformance has now reached the stage where a company's environmental disclosures reveal little about the company's environmental commitment, because disclosures are provided in an accepted or uniform way. Social disclosures however do not appear to have reached this level of professionalization and taken-for-grantedness yet.

The next section provides background to the mining industry and social issues in South Africa. This is followed by the theoretical perspective, method, findings, and concluding remarks.

\section{Background}

Since 1994, South Africa has been a democracy with freedom of expression and a free media. Despite a highly sophisticated corporate and financial sector, the 2006 gross national income per capita of US\$5,410 means that South Africa is classified as an "upper middle income" country (World Bank, 2009).

South Africa does however possess a number of Third World characteristics. Life expectancy at birth is 50.7 years, while the infant mortality rate is 49.6 per 1,000 live births. The low life expectancy is, among other reasons, attributable to HIV/AIDS, with 5.2 million people living with HIV/AIDs, including almost one third of women aged 25-29, and over a quarter of men aged 30-34. Over 250,000 South Africans died of AIDS in 2008, leaving 
many orphaned children without assets or incomes, and causing 20 per cent of the 1.4 million AIDS orphans not attend school (Avert, 2009). On a population-wide basis, HIV prevalence is estimated at $18.2 \%$ in South Africa (Avert, 2009). These infection rates among the working age population have major social and economic impacts.

The employment status of individuals influences their social well-being. South Africa has high rates of unemployment. During the second quarter of 2009, the official unemployment rate was 23.1 per cent (Statistics South Africa, 2009). However, closer inspection shows that only $44.7 \%$ of 15-64 year olds were employed and categories such as "discouraged work seekers" were not included in the unemployment percentage. Of those classified as "employed $17.0 \%$ are in the "informal sector", implying that they do not have regular jobs with regular incomes.

The South African mining industry has been implicated in these social concerns. It attracts thousands of male workers from poor, remote regions where unemployment rates are high. In many cases, they live in all-male hostels segregated from their families. As a result the sex industry flourishes, facilitating the spread of HIV. Mining companies have now implemented prevention programmes, while some provide family accommodation (Avert, 2009; Lawrence and Samkin, 2005; Samkin and Lawrence, 2007).

In a developing country, such as South Africa, the mining industry is a significant employment and wealth provider. The industry "accounts for over $10 \%$ of world gold production, and is the leading producer of platinum, manganese, titanium, chrome, zirconium and vanadium... It is also South Africa's biggest employer, with around 460,000 employees and another 400,000 employed by the suppliers of goods and services to the industry" (International Marketing Council of South Africa (IMC), 2009). 
Although mining provides substantial economic benefits, there are major negative environmental and other social impacts associated with this industry. These include nonsustainable land use, exhaustion of non-renewable resources, as well as a variety of health and safety concerns (Azapagic, 2004). These negative impacts have caused pressure groups to demand more sustainability disclosure and non-financial disclosures from mining companies.

The specific sustainability disclosures of large mining companies differ (Jenkins and Yakovleva, 2006; Perez and Sanchez, 2009). This may be in part due to the information needs of diverse stakeholders. For example, environmental issues, such as water, energy and biodiversity conservation, and greenhouse gas emissions, are of most interest to insurers, local communities, local authorities, governments and (Non-Governmental Organisations' (NGO's) (Azapagic, 2004), while social issues, such as employment, skills development, and health and safety, are of most interest to employees and trade unions (Azapagic, 2004).

Prior research has shown that community pressure groups, NGO's and stakeholders are able to influence corporate social disclosures (Tilt, 1994; Gray, Owen, and Adams, 1996; De Villiers and Lubbe, 2001; Hasseldine et al., 2005; Mitchell and Quinn, 2005; Schepers, 2006; De Villiers and Van Staden, 2010). The increase in environmental organisation membership has been specifically linked with increases in corporate environmental disclosures (Deegan and Gordon, 1996). Additionally, Deegan and Blomquist (2006) illustrate how the environmental reporting of an Australian mining company was influenced by a particular NGO, the World-Wide Fund for Nature.

Sustainability disclosure is conceptualised by Georgakopoulos and Thomson (2008) as a contest whereby companies engage with stakeholders, regulators, political institutions and the general public. The contest is mediated by issue amplifiers, such as the media. Media attention specifically influences sustainability disclosure content, as shown by Ader (1995), 
Brown and Deegan (1998), and Patten (2002). Additionally, Deegan, Rankin, and Tobin (2002) show a link between media attention on specific social issues and social disclosures by the mining company BHP. Overall, the prior literature suggests that stakeholders influence sustainability disclosure.

South Africa's free media enables stakeholders to potentially exert the pressure necessary to influence sustainability disclosure. This can occur through political means (by making public speeches, organising protest marches, and strikes), or using various media forms (Brown and Deegan, 1998) to disseminate their message.

By engaging with the political system and the media, stakeholder groups can influence both the social and the environmental agenda of companies. In the South African context, an example of a powerful stakeholder group is the trade union Cosatu (Congress of South African Trade Unions). Cosatu revealed the extent of its power in 2008 by replacing the president of South African and of the ANC, Thabo Mbeki with their preferred candidate, Jacob Zuma. Their rational for this overthrow was that Mbeki followed policies that did not benefit ordinary workers. Although Cosatu is able to exert significant political influence, the organisation is primarily interested in employee working conditions. Cosatu's remit means that the organisation is particularly interested in employment matters classified as social information in corporate disclosures (Azapagic, 2004).

South African listing requirements and accounting standards are similar, and it could be argued in some instances exceed First World requirements. International Financial Reporting Standard (IFRS) are mandatory. Good corporate governance practice and disclosures are encouraged by the King II guidelines (now King III, but King II at the time the disclosures were examined). These disclosure and listing rules lead to similarities in sustainability disclosure among companies. For example, South African social and environmental legislation requires all mines to rehabilitate land at the end of their mining operations 
meaning the attendant environmental liability must be disclosed. Rules also cause similar concerns among stakeholders. For example, stakeholders may require information regarding the impact of employment or environmental rules on future cash flows.

Mining company managers, accountants, and public relations professionals are typically MBA, engineering or business degree graduates. Internationally, the curricula for these qualifications tend to be similar because universities and professional bodies follow international best practice. However because business programmes are implicitly based on neo-classical economic underpinnings, engineering graduates who move into management pick up these cues from their business graduate colleagues. This suggests that mining company managers can be expected to base decisions, including sustainability disclosure formats and content, on similar principles.

\section{Theoretical perspective}

Organisations experience pressures that lead them to adopt rules and structures to enhance legitimacy in order to maintain access to resources (DiMaggio and Powell, 1983; Deephouse, 1996). These organisational responses lead them to become isomorphic with their environment. Because organisations in similar positions in a field experience comparable pressures, they tend to adopt similar rules and structures that reflect managers' taken-for-granted beliefs (Heugens and Lander, 2009). Drawing on this premise, studies using an institutional theory framework can focus either on rules and structures or on beliefs. Focusing on observable rules and structures without the need to examine managers' beliefs is known as the structuralist approach. This can be contrasted with the agency approach, where managers' beliefs take centre stage (Scott, 2008b). In this paper, the structuralist approach is considered appropriate as content analysis does not permit a direct examination of managers' beliefs. 
DiMaggio and Powell (1983) identify three types of isomorphic forces, namely mimetic, coercive and normative. Mimetic refers to companies benchmarking (or copying) each other, coercive refers to companies being strong-armed into a course of action, while normative refers to the professionalization of norms (Dacin, 1997; Haveman, 1993). Each of these isomorphic forces can be used to explain how changes in changes in sustainability disclosure among mining companies can occur.

BHP Billiton (not in the sample as it is also listed outside South Africa), is the largest mining company in South Africa. The company was formed when BHP (Australian) and Billiton (South African) merged. The previous CEO was a South African. As a result, many South Africans consider BHP Billiton to be a local company. Not only is BHP Billiton large and successful, it is also considered a leader in social and environmental reporting (Perez and Sanchez, 2009). BHP Billiton follows the GRI reporting guidelines and South African mining companies may regard BHP Billiton's sustainability disclosure as the standard against which they benchmark their own reports. As BHP Billiton's sustainability disclosure and the sustainability disclosure field changes and converges over time, this process is described as mimetic isomorphism.

Regulators, the capital markets, and stakeholder (such as Greenpeace and Cosatu) apply pressure that can result in coercive isomorphism in sustainability disclosure. An example of this form of coercive isomorphism is the legislation of mining company practice and annual report disclosures. In South Africa, before a mining licence is issued, authorities require an approved environmental rehabilitation programme to be in place. This means that mining companies generally disclose a provision for a rehabilitation liability in their financial statements.

Normative isomorphism takes place when companies internalise the norms that derive from the professionalization of a field (DiMaggio and Powell, 1983; Mizruchi and Fein, 
1999; Suddaby and Viale, 2011). Companies seek professional sustainability disclosure guidance from consultants and published guidelines, for example those published by the Global Reporting Initiative (GRI). GRI's normative nature is revealed in the first sentence of the executive summary, which reads: "The Sustainability Reporting Guidelines help organizations determine what they should report on and how they should report it". (GRI, 2009b: 1, emphasis added). Companies increasingly follow the GRI guidelines (KPMG, $2008,2011)$, because they take-for-granted that this is the 'right thing to do'.

A natural progression is often evident in the development of a new field (Tuttle and Dillard, 2007). A new field often creates much innovation and uncertainty (Delmas, 2002). Convergence tends to commence when companies respond to this uncertainty by copying others (mimetic isomorphism). Over time, increased regulation and societal expectations in the field results in coercive isomorphism. As the field matures, normative isomorphism through professionalization becomes an important factor (Suddaby and Viale, 2011). However, the three types of isomorphic forces "can and, generally do, operate simultaneously" (Tuttle and Dillard, 2007: 392). Apart from organisational change, field level change may be caused by professionalization (Suddaby and Viale, 2011). Therefore it might be expected that the field of sustainability disclosure reaches the stage where normative isomorphism predominates, but where elements of mimetic and coercive isomorphism remain.

Table 1 details the general transition of a field from the early stages where mimetic and coercive isomorphism prevails to the later, mature stage where normative isomorphism predominates. The first three rows deal with general theoretical expectations, while the final illustrates how the framework has been applied to the field of mining company sustainability disclosure. 
Table 1 The maturation and convergence of the field of sustainability disclosure

\begin{tabular}{|c|c|c|c|}
\hline & $\begin{array}{c}\text { MIMETIC } \\
\text { ISOMORPHISM }\end{array}$ & $\begin{array}{c}\text { COERCIVE } \\
\text { ISOMORPHISM }\end{array}$ & $\begin{array}{c}\text { NORMATIVE } \\
\text { ISOMORPHISM }\end{array}$ \\
\hline DESCRIPTION & $\begin{array}{l}\text { Early stages } \\
\text { characterised by } \\
\text { uncertainty around } \\
\text { the appropriate } \\
\text { response to the } \\
\text { pressures }\end{array}$ & $\begin{array}{l}\text { Early stages, but } \\
\text { pressures are starting } \\
\text { to formalise around } \\
\text { new regulations and } \\
\text { demands from } \\
\text { influential } \\
\text { stakeholders }\end{array}$ & $\begin{array}{l}\text { Towards maturity } \\
\text { through } \\
\text { professionalization } \\
\text { driven by similar } \\
\text { training and social } \\
\text { interaction } \\
\text { between } \\
\text { professionals }\end{array}$ \\
\hline DOMINANT LOGIC & $\begin{array}{l}\text { Copy successful } \\
\text { competitor }\end{array}$ & Conform to demands & $\begin{array}{l}\text { Conform to taken- } \\
\text { for-granted norms }\end{array}$ \\
\hline PROCESSES & $\begin{array}{l}\text { Benchmarking and } \\
\text { identifying best } \\
\text { practice }\end{array}$ & $\begin{array}{l}\text { Formal and informal } \\
\text { influence }\end{array}$ & $\begin{array}{l}\text { Internalisation of } \\
\text { new norms }\end{array}$ \\
\hline $\begin{array}{l}\text { APPLIED TO MINING } \\
\text { COMPANY } \\
\text { SUSTAINABILITY } \\
\text { DISCLOSURE }\end{array}$ & $\begin{array}{l}\text { Mining companies } \\
\text { follow the example } \\
\text { of large, profitable } \\
\text { mining companies, } \\
\text { such as BHP Billiton }\end{array}$ & $\begin{array}{l}\text { Mining companies } \\
\text { disclose in response } \\
\text { to legislation or pre- } \\
\text { empting legislation, } \\
\text { i.e. following IFRS, } \\
\text { and corporate } \\
\text { governance guidelines }\end{array}$ & $\begin{array}{l}\text { Mining company } \\
\text { managers and } \\
\text { consultants } \\
\text { develop shared } \\
\text { norms around SR, } \\
\text { taking for granted } \\
\text { that certain SR } \\
\text { guidelines should } \\
\text { be followed }\end{array}$ \\
\hline
\end{tabular}

Developed by building on DiMaggio and Powell (1983), and Tuttle and Dillard (2007)

Both mimetic and coercive influences can lead to normative isomorphism. For example, other South African mining companies start to copy BHP Billiton's adherence to the GRI disclosure framework, the GRI disclosure framework becomes the norm all mining companies view as the new accepted professional standard. An example of coercive isomorphism leading to normative isomorphism occurs when stakeholders demand that mining companies demonstrate corporate social responsibility. Mining companies may find that adopting the GRI disclosure framework provides a credible and defensible response. Over time the fact that many mining companies follow GRI leads professionals to regard GRI 
as the new accepted norm. All three types of isomorphism generally co-exist at all times even after a field has reached maturity.

\section{Method}

The impact of company size and industry on sustainability disclosure is well documented in the literature. Size is integral to the research design of this paper, as large and small company disclosures are compared. Industry is held constant by only including mining companies in the sample. Only data from listed companies is included to ensure availability and visibility. Cross-listed companies are excluded to increase the likelihood that companies are only exposed to country-specific pressures. There were 18 mining companies that were only listed on the Johannesburg Securities Exchange (JSE) on 31 December 2007.

As managers choose the vehicle through which to disclose sustainability information based on particular circumstances (De Villiers and Van Staden, 2011), this study analysed both annual reports and websites. The reason for including websites in the study was that separate sustainability reports are typically found on these forums. A content analysis of the 18 companies' 2007 annual reports and websites (including standalone reports) was carried out during 2008 and took the form of a sentence count of the social and environmental disclosure items suggested by the following guidelines: the GRI G3 guideline including the mining sector supplement (2009a; 2009b); SustainAbility (2006); the International Institute for Environment and Development (2002) multi-stakeholder appraisal of sustainability in mining; and the International Council on Mining and Metals (2002). In addition, the content analysis also includes disclosure items suggested in the prior literature (Deegan et al., 2002; Azapagic, 2004; Hackston and Milne, 1996; Davis-Walling and Batterman, 1997; Milne et al., 2003). 
In the analysis of websites, links that lead away from the company website to other sites were not followed. All links were followed from the main website page to links that address the social and environmental issues (see below). Sentences (including graphs and tables) were counted, as well as various quality characteristics of the sentences based on Hackston and Milne (1996). Managers decide how much information should be disclosed in annual reports (O’Dwyer, 2002). Volumes and characteristics of disclosures are therefore indications of the importance managers attach to social and environmental issues in response to stakeholder pressures. A limitation of studies involving the use of checklists typically ignores these manager signals. Note also that content analyses using quality measures (checklist type) versus extent measures (used in this study), yield similar results (Hooks and Van Staden, 2011).

In order to facilitate the comparison of disclosures between different companies, their patterns and characteristics are recorded rather than the specific information. The reason for this is that the disclosure wording invariably differs between companies (Perez and Sanchez, 2009; Jenkins and Yakovleva, 2006). Drawing on Hackston and Milne (1996), the content analysis also captured whether sentences represented good, bad or neutral news from the perspective of the company. For example, a sentence describing an environmental policy would be classified as a neutral environmental disclosure. Admitting to an environmental disaster, such as the collapse of a sludge dam, would be classified as a negative environmental disclosure. Finally, disclosures of any remediation work would be classified as a positive environmental disclosure. This classification facilitates the comparison of positive sustainability disclosure, which is likely to increase in response to bad news (Deegan and Rankin, 1996). In this way it was possible to compare both quantitative and qualitative aspects of the companies' overall disclosures. Although smaller companies might have fewer 
separate mining sites, the site level concerns highlighted by Mudd (2009; 2011) were unable to be addressed.

The content analysis described above was undertaken by a single researcher. Milne and Adler (1999) argue that inexperienced content analysers can be relied on for aggregate disclosure analysis. The coder employed in this study is highly experienced, having analysed 100 annual reports for a previous study using the Hackston and Milne (1996) method. To facilitate comparison of the social and environmental reporting, quality scores were calculated according to Hackston and Milne (1996). The number of sentence containing monetary information was multiplied by 4 . Sentences with quantitative (but not monetary) information were multiplied by 3. Narrative sentences containing specific information was multiplied by 2 , while each narrative non-specific sentence was multiplied by 1 . To clarify, sentences were coded to the highest applicable score. These scores were then summed. In this way, the quality score takes into account the way disclosure is made rather than just taking volume into account. An audit on the analysis found the coding and the interpretation to be accurate, after a few specific issues were discussed and agreed upon between the researchers and the coder.

For the purposes of this paper, large companies were defined as those with a market capitalisation above 4 billion Rand (on 31 December 2007, the exchange rate was ZAR6.81 to USD1). This yielded two samples of equal size. The statistical comparison of the difference between the disclosures of large mining company sustainability disclosure with small company sustainability disclosure was done by way of ANOVA. Overall disclosures are initially compared, followed by the comparison of smaller categories and sub-categories of disclosure.

DiMaggio and Powell (1983) argue that professionals develop the same shared takenfor-grated attitudes about the best way to deal with a specific field as a consequence of their 
training coupled with membership of professional bodies. Data was also collected that relate to the level of professionalization in the sample companies. Specifically, relating to the qualifications (where these are disclosed) of directors', senior managers' and the providers of assurance services. The more commonality between the qualifications of directors and senior managers, and the more they use the same assurance providers, the more likely it is that these mining companies will develop similar attitudes about the 'right way' that sustainability disclosure 'should' be made.

\section{Findings}

The research findings are detailed in Table 2. The rows in the first column describe the data. The next two columns provide the information on the small companies in the sample. This is followed by the information on the large companies. The final two columns detail the results of the statistical comparison between the two sub-samples using an ANOVA. However where the homogeneity of variance test was significant, the Welch and BrownForsythe test results are shown.

The first comparison shows the difference in size of the companies. The average market capitalisation of the small companies in the sample averages approximately one billion Rand, while the larger companies average approximately 20 billion Rand. The difference between the two is, as expected, significant.

Panel A compares the number of sentences of social and environmental information disclosed. The results show that large companies disclose more social information than small companies which is statistically significant at the $10 \%$ level. This result is expected. Because of increased social pressures on large companies they need to increase their disclosures to ensure that legitimacy is maintained and thus continued access to resources. That there is no statistically significance difference between the amount of environmental disclosures made 
Table 2 South African mining companies social and environmental annual report and website disclosures

\begin{tabular}{|c|c|c|c|c|c|c|c|c|}
\hline \multirow[t]{2}{*}{ Average number of sentences } & \multicolumn{3}{|c|}{$\begin{array}{l}\text { Smaller co. by market } \\
\text { cap. }\end{array}$} & \multicolumn{3}{|c|}{ Larger co. by market cap. } & \multicolumn{2}{|c|}{ ANOVA } \\
\hline & Mean & Std Dev & $\mathrm{n}$ & Mean & Std Dev & $\mathrm{n}$ & F-stat & $P$ value \\
\hline $\begin{array}{l}\text { Size - market cap. - millions of } \\
\text { Rand }\end{array}$ & 979.738 & 1079.740 & 9 & 19874.270 & 28238.361 & 9 & 4.023 & 0.080 \\
\hline \multicolumn{9}{|c|}{ Panel A: Number of sentences overall } \\
\hline Social disclosure & 135.667 & 157.884 & 9 & 533.667 & 534.522 & 9 & 4.589 & 0.060 \\
\hline Environmental disclosure & 55.667 & 66.493 & 9 & 184.889 & 217.895 & 9 & 2.896 & 0.121 \\
\hline \multicolumn{9}{|l|}{ Panel B: Quality scores* overall } \\
\hline Social disclosures & 222.556 & 274.481 & 9 & 842.889 & 841.863 & 9 & 4.417 & 0.063 \\
\hline Environmental disclosures & 99.667 & 98.080 & 9 & 266.000 & 295.320 & 9 & 2.571 & 0.141 \\
\hline \multicolumn{9}{|c|}{$\begin{array}{l}\text { *Quality scores were calculated by multiplying each sentence containing monetary information by } 4 \text {, each } \\
\text { sentence with quantitative (but not monetary) by } 3 \text {, each narrative sentence containing specific information } \\
\text { by } 2 \text {, each narrative non-specific sentence by } 1 \text {, and then adding all these scores together. }\end{array}$} \\
\hline \multicolumn{9}{|c|}{ Panel C: By Good, Bad, Neutral news from a company's perspective (number of sentences) } \\
\hline Social - good news & 26.889 & 33.138 & 9 & 89.222 & 84.041 & 9 & 4.285 & 0.064 \\
\hline Social - bad news & 4.333 & 3.445 & 6 & 12.375 & 11.575 & 8 & 3.453 & 0.086 \\
\hline Social - neutral news & 105.889 & 133.454 & 9 & 433.444 & 444.343 & 9 & 4.486 & 0.062 \\
\hline Environment - good news & 7.250 & 11.511 & 8 & 17.333 & 16.439 & 9 & 2.091 & 0.169 \\
\hline Environment - bad news & 3.000 & 2.828 & 2 & 11.667 & 12.388 & 6 & 2.539 & 0.162 \\
\hline Environment - neutral news & 48.556 & 54.293 & 9 & 159.778 & 191.042 & 9 & 2.823 & 0.126 \\
\hline \multicolumn{9}{|c|}{ Panel D: By disclosure medium (number of sentences) } \\
\hline Social - Annual report & 106.556 & 125.091 & 9 & 361.111 & 326.823 & 9 & 4.762 & 0.053 \\
\hline Social - Financial Statement & 24.875 & 27.026 & 8 & 89.889 & 98.296 & 9 & 3.629 & 0.088 \\
\hline Social - Rest of Annual Report & 84.444 & 102.257 & 9 & 271.222 & 232.058 & 9 & 4.882 & 0.042 \\
\hline Social - Website & 43.667 & 41.831 & 6 & 172.556 & 211.897 & 9 & 3.146 & 0.110 \\
\hline Environment - Annual report & 48.875 & 49.812 & 8 & 116.889 & 126.883 & 9 & 2.011 & 0.177 \\
\hline Environment - Fin. Statement & 19.000 & 19.243 & 8 & 26.250 & 18.148 & 8 & 0.601 & 0.451 \\
\hline $\begin{array}{l}\text { Environment - Rest of Annual } \\
\text { Rep. }\end{array}$ & 29.875 & 44.341 & 8 & 93.556 & 112.948 & 9 & 2.438 & 0.148 \\
\hline Environment - Website & 18.333 & 22.669 & 6 & 76.500 & 95.879 & 8 & 2.740 & 0.136 \\
\hline
\end{tabular}

F-statistics and P-Values reflect the Welch and Brown-Forsythe Test values, because the 'Homogeneity of Variance' test was significant. Highlighted F-statistics and P-Values reflect the normal ANOVA test values.

by large and small companies could be considered surprising. As is more fully argued earlier in the paper, this could possibly be explained by the field of environmental disclosures 
having reached a level of maturity and professionalization that all mining companies, regardless of size, are motivated to disclose similar amounts of environmental information.

Panel B compares the quality scores of social and environmental reporting. These results show a statistically significant difference between the social disclosures of large and small companies, but no difference in environmental disclosures. This comparison provides evidence, that large and small companies disclose environmental matters similarly. Not only are the same number of sentences disclosed, but similar qualitative patterns are used.

The analyses thus far show that comparing the social and environmental disclosures of large and small companies using two different methods of measuring disclosure yield similar results. That is large companies disclose more social information but large and small companies disclose similar levels of environmental information.

Panel $\mathrm{C}$ provides further detail by breaking both social and environmental disclosure into good news, bad news, and neutral news categories. This comparison is undertaken to illustrate that the similarities and differences identified above persist even when social and environmental disclosures are broken down into smaller categories. The results show that large companies disclose statistically significantly more good social information, bad social information, and neutral social information than small companies. However, the comparisons between large and small companies' environmental disclosures, whether it is good news, bad news, or neutral news disclosures, show that these disclosure categories are not statistically significantly different. This provides additional evidence that environmental disclosure has reached a level of conformity, suggesting a level of maturity of the field that may be driven by the professionalization of the field.

Panel D shows a comparison of disclosures based on where they were made. The social and environmental disclosures are broken down into annual report and website disclosures. 
Again, large companies are shown to disclose more social information than small companies, both in annual reports and on websites. This difference is not statistically significant in the case of website social disclosure, although the p-value at 0.11 is close to the chosen cut-off point of 0.10 . Consistent with the earlier findings, there is no statistical significance in any of the comparisons of environmental disclosures made by large and small companies, i.e. environmental disclosures are similar irrespective of the size of the company. Given the overwhelming evidence in the prior research that large companies disclose more information than small companies, this finding is remarkable. The most likely explanation for this finding remains that the field of environmental reporting among mining companies has reached a level of maturity and professionalization and taken-for-grantedness that all companies feel compelled to "do the right thing" and disclose environmental information to a socially acceptable level.

Annual reports can be divided into the financial statement part of the annual report and the more descriptive part that focus on an overview of operations and provide narrative social and environmental information. The results that social disclosures are different and environmental disclosures are similar in annual reports may be driven by one or the other part of annual reports. Therefore, a way to further examine the data is to drill down to the level of financial statements and the rest of the annual report. Panel D shows that there are statistically significant differences (bigger companies disclosing more) in social disclosures both in financial statements and in the rest of the annual report. However, there are no statistically significant differences in environmental disclosures in either the financial statements or the rest of the annual reports. These results provide further evidence that environmental disclosures by mining companies have reached a new level of maturity, a level of maturity that is different from social disclosures. 
Table 3: Company characteristics consistent with professionalization

Qualifications held by directors and senior managers as disclosed in the 18 companies' annual reports

\begin{tabular}{|c|c|}
\hline & $\begin{array}{c}\text { Number of } \\
\text { directors and } \\
\text { senior } \\
\text { managers }\end{array}$ \\
\hline $\begin{array}{c}\text { Engineering and } \\
\text { Science Degrees }\end{array}$ & 57 \\
\hline CAs & 31 \\
\hline MBAs & 25 \\
\hline Business Degrees & 21 \\
\hline Law Degrees & 18 \\
\hline Accounting Degrees & 7 \\
\hline
\end{tabular}

Each director and manager appears once in the table.

Assurance services used as disclosed in annual reports and sustainability reports

\begin{tabular}{|c|c|c|}
\hline $\begin{array}{c}\text { Assurance } \\
\text { services provided } \\
\text { by }\end{array}$ & BIG 4 auditor & 14 \\
\cline { 2 - 3 } & Other & 4 \\
\hline
\end{tabular}

Normative isomorphism is characterised by professionalization, whereby education, training, social interaction, and professional membership play important roles in shaping individuals' beliefs towards shared norms. Additional evidence supporting the notion that there is a certain amount of professionalization within mining companies that is bound to spill over into the field of sustainability disclosure, can be found in the shared qualifications of the directors and senior managers. Table 3 details the qualifications held by directors and senior managers within the 18 sample companies. Of the directors and senior managers in the 
sample companies, 57 held engineering or science degrees, 31 held professional accounting qualifications, 25 held with MBAs, another 28 had business or commerce degrees, while 18 held law degrees. Thus, in total, 84 directors or senior managers have a business or accounting education. This provides evidence of professionalization in terms of the shared training and understandings of mining company leaders.

Table 3 also show that 14 of the 18 companies are audited by one of the BIG 4 audit firms. This provides further evidence of professional influences emanating from a small base of four large audit firms. Auditors specifically focus on and influence reporting, including sustainability disclosure. Audit firms are leaders in sustainability consultancy and sustainability audits, actively pursuing sustainability services (O’Dwyer et al., 2011). The reporting advice audit firms offer are likely to embody prevalent norms, thus professionalising sustainability disclosure in a process of normative isomorphism.

As mentioned before, the GRI reporting guidelines are normative in nature and are recommended by professionals and consultants. Sustainability disclosure is bound to converge as more companies follow the GRI guidelines. The GRI mining industry framework is contributing to even "further standardisation" (Azapagic, 2004: 640). As an example, one of the sample companies reports: "This report has been prepared using the Global Reporting Initiatives (GRI) Guidelines and the Mining and Metals Sector Supplement as a framework." The company also provides their GRI application level. Two companies in the sample, one in the "large" and one in the "small" group also referred to stakeholders using the same wording, namely: "This framework has been designed to provide comprehensive information to stakeholders of an organisation on economic, social and environmental performance that make up its triple bottom line." Bearing in mind that these companies are completely different and has no obvious relationship with each other, this repeated statement appears to be GRI inspired. 


\section{Concluding remarks}

This paper uses an institutional theory framework to examine the sustainability disclosures of mining companies. The aim of the study was to gain a better understanding of the level of institutionalisation (maturity) reached in this field. Institutional theory suggests that a new field is characterised by uncertainty and innovation, which leads some organisations to mimic the practices of successful organisations in order to deal with the uncertainty. Over time regulation and further stakeholder demands coerce organisations into further conformance. This is followed by a phase where professionals both within (directors and managers) and outside the organisation (e.g. consultants) develop a normative approach to the field, i.e. there is a new taken-for-granted way of doing things, a way things should be done. When a field reaches this level of maturity, conformance reaches a level where almost all organisations follow the new institution in more or less the same fashion. Differences in the rules and structures previously adopted by organisations with different characteristics to deal with societal pressures start to disappear as a shared understanding of the way to deal with these pressures develops.

Corporate social and environmental disclosure developed as a response to pressures and represented a new field in the 1960s and 1970s. The professionalization of this field can be seen through organisations like the GRI. For example, a recent GRI Conference held in Amsterdam, Netherlands, to launch the GRI G4 reporting framework was attended by more than 1,600 delegates from all over the world. Ninety per cent of the attendees were professionals, either employed by companies in roles related to social and environmental disclosure matters, or consultants who provide consulting and assurance services in this field. The field is also increasingly covered in tertiary education courses aimed at the initial or the continued education of managers and other professionals. 
One of the most consistent indicators of the likelihood of companies to disclose social and environmental information has always been size, with large companies being more likely to disclose and also disclosing greater volumes of information. The analyses in this paper compared the disclosure of smaller listed mining companies to larger listed mining companies and find the expected differences when comparing social disclosures, however, no statistical significance was found in environmental disclosures. These findings suggest that the field of environmental disclosure among mining companies has reached a level of maturity and conformance associated with the professionalization of a field. It appears to be taken-for-granted that a certain amount of environmental disclosure should be done. Mining companies large and small now disclose environmental information in relatively uniform ways (a similar number of sentences, published in similar locations, displaying similar characteristics, such as good/bad/neutral news, and monetary/quantitative/specific/general information). With this level of conformity, it appears to be reasonable to conclude that an analysis of these characteristics of corporate environmental disclosure may in future not yield many meaningful results. Such a conclusion has major implications for the research community, but also for various stakeholders who may have regarded corporate environmental disclosures as meaningful indicators of corporate intent.

\section{REFERENCES}

Ader, C. R., 1995. A longitudinal study of agenda setting for the issue of environmental pollution. Journalism \& Mass Communication Quarterly 72 (2), 300-311.

Avert, 2009. HIV and AIDS in South Africa, available on the internet at: http://www.avert.org/aidssouthafrica.htm. Accessed 19.08.09.

Azapagic, A., 2004. Developing a framework for sustainable development indicators for the mining and minerals industry. Journal of Cleaner Production 12 (6), 639-662.

Brown, N., Deegan, C., 1998. The public disclosure of environmental performance information a dual test of media agenda setting theory and legitimacy theory. Accounting and Business Research 29 (1), 21-41.

Dacin, M. T., 1997. Isomorphism in context: The power and prescription of institutional norms. Academy of Management Journal 40 (1), 46-81. 
Davis-Walling, P., Batterman, S. A., 1997. Environmental reporting by the Fortune 50 firms. Environmental Management 21 (6), 865-875.

De Villiers, C. J., Lubbe, D. S., 2001. Industry differences in respect of corporate environmental reporting in South Africa: A research note. Meditari Accountancy Research 9 (1), 81-91.

De Villiers, C., Van Staden, C., 2011. Why do shareholders' require corporate environmental disclosure? South African Journal of Economic and Management Sciences 13 (4), 437446.

De Villiers, C., Van Staden, C., 2011. Where firms choose to disclose voluntary environmental information. Journal of Accounting and Public Policy 30 (6), 504-525.

Deegan, C., Blomquist, C., 2006. Stakeholder influence on corporate reporting: An exploration of the interaction between the World Wide Fund for Nature and the Australian minerals industry. Accounting, Organizations and Society 31 (4-5), 343-372.

Deegan, C., Gordon, B., 1996. A study of the environmental disclosure practices of Australian corporations. Accounting and Business Research 26 (3), 187-199.

Deegan, C., Rankin, R., 1996. Do Australian companies report environmental news objectively? An analysis of environmental disclosures by firms prosecuted successfully by the environmental protection authority. Accounting, Auditing \& Accountability Journal 9 (2), 50-67.

Deegan, C., Rankin, M., Tobin, J., 2002. An examination of the corporate social and environmental disclosures of BHP from 1983-1997. A test of legitimacy theory. Accounting, Auditing \& Accountability Journal 15 (3), 312-343.

Deephouse, D. L., 1996. Does isomorphism legitimate? Academy of Management Journal 39 (4), 1024-1039.

Delmas, M. A., 2002. The diffusion of environmental management standards in Europe and in the United States: An institutional perspective. Policy Sciences 35, 91-119.

DiMaggio, P. J., Powell, W. W., 1983. The iron cage revisited: Institutional isomorphism and collective rationality in organizational fields. American Sociological Review 48, 147160.

Gamble, G. O., Hsu, K., Jackson, C., Tollerson, C. D. 1996. Environmental disclosures in annual reports: An international perspective. The International Journal of Accounting, 31 (3), 293-331.

Georgakopoulos, G., Thomson, I., 2008. Social reporting, engagements, controversies and conflict in an arena context. Accounting, Auditing \& Accountability Journal 21 (8), 1116-1143.

Gray, R., 2010. Is accounting for sustainability actually accounting for sustainability....and how would we know? An exploration of narratives of organisations and the planet. Accounting, Organizations and Society 35 (1), 47-62.

Gray, R., Owen, D., Adams, C. A., 1996. Accounting and Accountability: Changes and Challenges in Corporate Social and Environmental Reporting. London: Prentice Hall.

GRI, 2009a. Sustainability Reporting Guidelines, available on the internet at: www.globalreporting.org/NR/rdonlyres/ED9E9B36-AB54-4DE1-BFF25F735235CA44/0/G3_GuidelinesENU.pdf. Accessed 19.08.09.

GRI, 2009b. The GRI guidelines: An executive summary, available on the intenet at: www.globalreporting.org/NR/rdonlyres/CF868D62-21F2-40DF-B090F061BBB4AC3B/0/G3_Executive_Summary.pdf. Accessed 19.08.09 .

Hackston, D., Milne, M. J., 1996. Some determinants of social and environmental disclosures in New Zealand companies. Accounting, Auditing \& Accountability Journal 9 (1), 77 108. 
Haveman, H. A., 1993. Follow the leader: Mimetic isomorphism and entry into new markets. Administrative Science Quarterly 38 (4), 593-627.

Hasseldine, J., Salama, A. I., Toms, J. S. 2005. Quantity versus quality: the impact of environmental disclosures on the reputations of UK Plcs. British Accounting Review 37 (2), 231-248.

Heugens, P., Lander, M., 2009. Structure! Agency! (And other quarrels): A meta-analysis of institutional theories of organization. Academy of Management Journal 52 (1), 61-85.

Hooks, J., Van Staden, C. J., 2011. Evaluating environmental disclosures: the relationship between quality and extent measures. British Accounting Review, 43 (3), 200-213.

ICMM, 2002. ICMM Sustainable Development Framework-ICMM Principles, International Council on Mining and Metals, London, available on the internet at: www.icmm.com/publications/ICMM_Principles_en.pdf. Accessed 19.08.09.

IIED, 2002. Breaking New Ground, International Institute for Environment Development. London: Earthscan.

International Marketing Council (IMC) of South Africa, 2009. SouthAfrica. Info, available on the internet at: www.southafrica.info/business/economy/sectors/mining.htm. Accessed 28.01.10.

Internet World Stats, 2010. Internet world stats: Usage and population statistics, available on the internet at: http://www.internetworldstats.com. Accessed 19.10.10.

Jenkins, H., Yakovleva, N., 2006. Corporate social responsibility in the mining industry: exploring trends in social and environmental disclosure. Journal of Cleaner Production $14,271-284$.

KPMG, 2006. Global mining reporting survey, available on the internet at: www.kpmg.ca/en/industries/enr/mining/documents/GMS2006_PRINTversion_midres. pdf. Accessed 25.08.09.

KPMG, 2008. International survey of corporate responsibility reporting, KPMG International, available on the internet at: www.kpmg.com. Accessed 3.05.09.

KPMG, 2011. Corporate Responsibility Survey 2011: Marching towards embracing sustainable development, KPMG International, available on the internet at: https://www.in.kpmg.com/SecureData/aci/Files/Corporate-Responsibilty-Survey-

Report.pdf. Accessed 18.06.11.

Lawrence, S., Samkin, G. 2005. Accounting for inclusiveness: the corporate response to the challenge of HIV/AIDs in South Africa. Advances in Public Interest Accounting 11, 97-116.

Milne, M. J., Adler, R. W., 1999. Exploring the reliability of social and environmental disclosures content analysis. Accounting, Auditing \& Accountability Journal 12 (2), 237-256.

Milne, M. J., Tregidga, H., Walton, S., 2003. The triple bottom line: benchmarking New Zealand's early reporters. University of Auckland Business Review 5 (2), 37-48.

Mitchell, C. G., Quinn, N. W., 2005. Environmental reporting disclosure in South Africa: A comparative study of the expectations of selected groups of preparers and users. Meditari Accountancy Research 13 (2), 17-33.

Mizruchi, M. S., Fein, L. C., 1999. The social construction of organizational knowledge: A study of the users of coercive, mimetic, and normative isomorphism. Administrative Science Quarterly 44, $653-683$.

Mudd, G. M., 2012. Sustainability Reporting and the Platinum Group Metals: A Global Mining Industry Leader? Platinum Metals Review 56 (1), 2-19.

Mudd, G. M., 2009. Sustainability reporting and mining - an assessment of the state of play for environmental indicators. In Proceedings of 4th International Conference on 
Sustainable Development Indicators in the Minerals Industry, Gold Coast, Australia, July.

Neu, D., Warsame, H., Pedwell, K. 1998. Managing public impressions: environmental disclosures in annual reports. Accounting, Organizations and Society 23 (3), 265-282.

O’Dwyer, B., 2002. Managerial perceptions of corporate social disclosure, an Irish story. Accounting, Auditing \& Accountability Journal 15 (3), 406-436.

O’Dwyer, B., Owen, D., Unerman, J., 2011. Seeking legitimacy for new assurance forms: The case of assurance on sustainability reporting. Accounting, Organizations and Society 36 (1), 31-52.

Patten, D.M., 2002. Media exposure, public policy pressure, and environmental disclosure: An examination of the impact of tri data availability. Accounting Forum 26 (2), 152 171.

Perez, F., Sanchez, L. E., 2009. Assessing the evolution of sustainability reporting in the mining sector. Environmental Management 43, 949-961.

Samkin, G., Lawrence, S. 2007 Institutional responses to the challenge of HIV/AIDS: the case of South Africa. In May, S. K., Cheney, G. \& Roper, J. (Eds). The Debate over Corporate Social Responsibility. Oxford University Press, 271-291.

Schepers, D. H., 2006. The impact of NGO network conflict on the corporate social responsibility strategies of multinational corporations. Business and Society 45 (3), 282-299.

Scott, W.R., 2008a. Approaching adulthood: the maturing of institutional theory. Theory and Society 37 (5), 427-442.

Scott, W.R., 2008b. Lords of the dance: professionals as institutional agents, Organization Studies 29 (2), 219-238.

Statistics South Africa, 2009. Stats online, available on the internet at: www.statssa.gov.za/keyindicators/keyindicators.asp. Accessed 19.08.09.

Suddaby, R., Viale, T., 2011. Professionals and field level change: Institutional work and the professional project. Current Sociology 59 (4), 423-442.

SustainAbility, 2006. Report assessment methodology - Global Reporters 2006, available on the internet at: www.sustainabilty.com/downloads public/insight_reports/GR_Methodology.pdf. Accessed 31.08.09.

Tilt, C. A., 1994. The influence of external pressure groups on corporate social disclosure some empirical evidence., Accounting, Auditing \& Accountability Journal 7 (4), 47-72.

Tilt, C. A., 2008. Environmental disclosure outside the annual report. International Journal of Management and Decision Making 9 (3), 288-309.

Tuttle, B., Dillard, J., 2007. Beyond competition: Institutional Isomorphism in U.S. Accounting research. Accounting Horizons 21 (4), 387-410.

Wong, L. T., Fryxell, G. E., 2004. Stakeholder influences on environmental management practices: a study of fleet operations in Hong Kong (SAR), China. Transportation Journal 43 (4), 22-35.

World Bank, 2009. Country classification table, available on the internet at web.worldbank.org/WBSITE/EXTERNAL/DATASTATISTICS/0,,contentMDK:2042 0458 menuPK:64133156 pagePK:64133150 piPK:64133175 theSitePK:239419,00.h

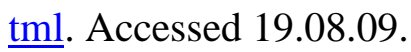

